\title{
Assessment of the Management Problems in Pandam Game Reserve, Plateau State, Nigeria
}

\author{
Anthony Fidelis Dung ${ }^{1}$ \\ Christian Ifeanyi Enete ${ }^{2}$ \\ Ifeanyi Chris Onwuadiochi ${ }^{3 *}$ \\ Nnamdi Azikiwe University, Awka, Anambra State, Nigeria ${ }^{1,2,3}$
}

\begin{abstract}
The study assesses the management problems in Pandam Game Reserve, Plateau State, Nigeria. Structured questionnaires, field survey and in depth interviews of key informants were used to obtain the data. Data were analyzed using descriptive statistics. The result reveals that inadequate infrastructures, shortage of staff and inadequate funds are the management problems of Pandam Game Reserve. The study asserts that inviting foreign investors would solve the problem of sustainable tourism development in Pandam Game Reserve. The study discovers that equipping rangers with modern facilities, increasing the staff strength, and payment of staff salaries would solve the management problems in Pandam Game Reserve. It asserts that outreach programs, stakeholders' involvement on tourism matters, and employing some community members, would curb the problems of ecosystem destruction by the host communities. The study therefore recommends government intervention to reposition the Pandam Game Reserve. This includes: provision of infrastructures, increasing the staff strength, and provision of funds. It also recommends that Government monitors activities around and within the Pandam Game Reserve so as to avoid poaching, land encroachment and deforestation. The study also recommends that: State Government gives proper attention to the implementation of tourism policies in Pandam Game Reserve; community involvement in the management procedures of Pandam Game Reserve; stakeholders to make more efforts to curb the problems at Pandam Game Reserve in order to make it more attractive to the tourists; foreign investors to be invited to help develop the Pandam Game Reserve to international standard.
\end{abstract}

Keywords: Game Reserve, Ecosystem, Management Problems, Sustainable Development, Tourism Industry

Corresponding author: Ifeanyi Chris Onwuadiochi; E-mail: ci.onwuadiochi@unizik.edu.ng DOI: https://doi.org/10.37227/ITHJ-2021-09-368

\section{Introduction}

Tourism has major economic significance for a country (Khan et al., 2020). The receipts from international tourism can provide a valuable source of employment and earnings for many countries, both developed and developing (Jansen, 2013; Khan et al., 2020). Furthermore, tourism can contribute to the infrastructure development as well so that tourists can travel smoothly. Parks exist in order to ensure that pleasure seekers enjoy their 
country's rich natural heritage (Nimmak and Onwuadiochi, 2020). Alamai, Kirfi, and Ladi (2018) state that Nigeria has the potentials to make tourism its main source of earnings, for it has vast tourist attractions, large domestic tourist market, and unique cultural settings which entice foreign tourists, but the country lacks the political will to implement and sustain its tourism policies and actions. Tourism has significant impact on Nigeria's economy, but the subsector still remains underinvested and underutilised (Eneji, Odey, and Bullus, 2016). Therefore, it is very much important to give attention to the issues in different subsectors of the tourism sector of the country.

Evidently, Nigeria is richly blessed with tourism potentials; but quite unfortunately, this is encapsulated by many problems bedeviling the tourism industry, such as management problems. This paper therefore seeks to discover these problems and recommend better ways for sustainable tourism development in the country and beyond.

\section{Literature Review}

Pandam Game Reserve Plateau State is the home of rare animal, stunning views and so on. Pandam Game Reserve was established by the Benue- Plateau State Legal Notice number 1 of 1972 with October 20, 1975 the date of commencement. It is a great natural animal habitation where many tourists and researchers from foreign countries come and explore different aspects. However, the Pandam Game Reserve now faces years of neglect. Veering off the road towards the reserve, the deploring state of the tourist village, which is supposedly chalets to accommodate tourists, hidden among towering trees, is the first thing any visitors stares at. There is also a multipurpose hall standing strong but obviously in need of a desperate make over, otherwise, the stakeholders cannot get the benefits of this structure. The game reserve is situated beside the Lafia-Shandam Road to the north of the Benue river. Moreover, it is barely a distance of 60 kilometres to Lafia, the capital of Nasarawa State, therefore, there is a great potential to draw numerous tourists to this place.

The rate of corruption in Nigeria is a huge discouragement to tourism, and this hinders the country from been a tourist destination (Osinubi et al., 2021). However, there is a need for quality and effective management of tourism and tourist destinations in Nigeria (Adeleke and Ogunsusi, 2019). This would however bring investors into the country, and thus foster sustainable tourism development (Jemirade, 2021). Planning and management entails personnel and qualified individuals who are skilled in the aspect of tourism (Mason, 2003).

Some of the management problems include security, infrastructural amenities, promotion and awareness, funding and financing, attitude and image (Ndanusa, Harada, and Islam, 2014). A study by Da'an, Jidangkat, Chaskda, and Mwansat (2020) shows the presence of some human activities, such as logging, firewood collection, fishing, farm encroachment, cattle grazing and poaching in Pandam Game Reserve. If left uncontrolled, the implication of these socioeconomic activities in Pandam Game Reserve could result to biodiversity loss (Da'an et al., 2020). A multi-stakeholder approach and participatory management of the reserve which considers the socioeconomic concerns of locals have been suggested as a critical component for building cooperation (Da'an et al., 2020).

Eagles (2002) states that ineffective management of ecotourism causes negative impact on protected area resources. It provides an alternative mechanism of resource utilization which may bring adverse impact on environmental resources (Sreekumar and Parayil, 2002). According to Nimmak, Phil-Eze, Ezenwaji and Onwuadiochi (2020), Pandam Game Reserve is faced with environmental challenges, such as destruction of wildlife species, unauthorized deforestation and inadequate infrastructure, and they assert 
that: government should invest in the ecotourism industry, facilities needed in the industry should be upgraded and/or provided, private investors should be encouraged, unauthorized logging and poaching should be abated, and capacity building for community members should be encouraged.

\section{The Study Area}

\section{Materials and Methods}

Pandam Wildlife Park is located North of Benue River (Ezealor, 2002) and South of Plateau State (Akosim, 1997) along Lafia-Shendam Road in Qua'an Pan Local Government Area of Plateau State (Ijeomah, 2007). It lies between latitudes $8^{0} 35^{1} \mathrm{~N}$ and $8^{0} 55^{1} \mathrm{~N}$, and longitudes $8^{0} 00^{1} \mathrm{E}$ and $8^{0} 45^{1} \mathrm{E}$ (Nimmak and Onwuadiochi, 2020). The park covers an area of 224 square kilometers (Nimmak and Onwuadiochi, 2020). Pandam Park is located at a height of 175 - 310 meters above sea level and it is bounded by a river to the North and by Pandam to the west and bounded by Namu, Kayarda and Aningo settlements to the south and east (Nimmak and Onwuadiochi, 2020).

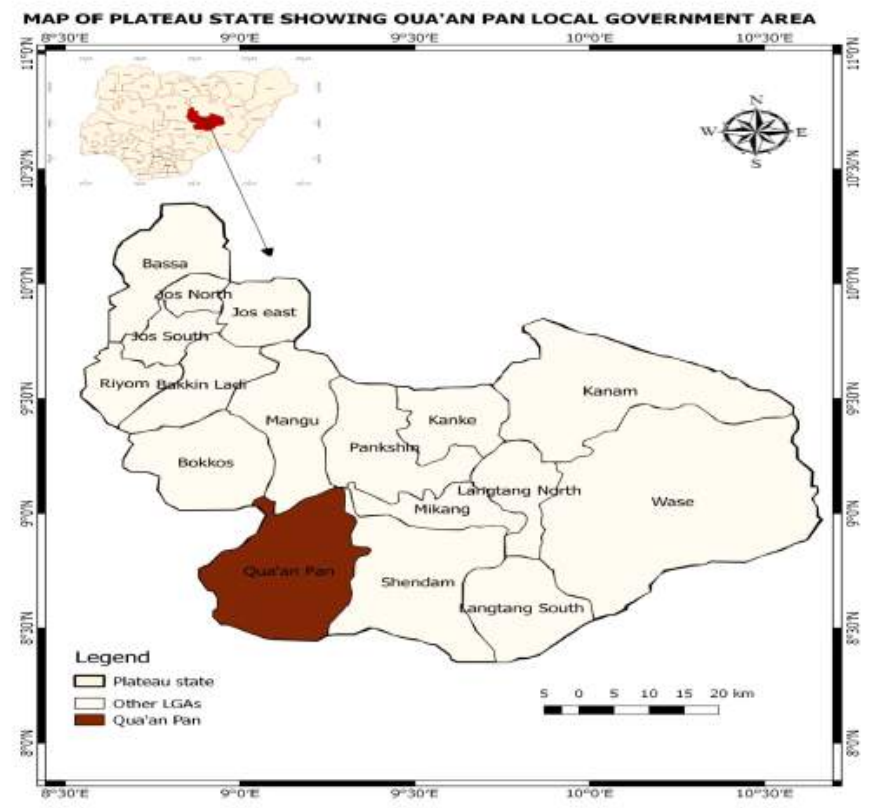

Fig. 1: Plateau State showing Qua'an Pan LGA Source: Plateau State Ministry of Land and Survey, 2010. 


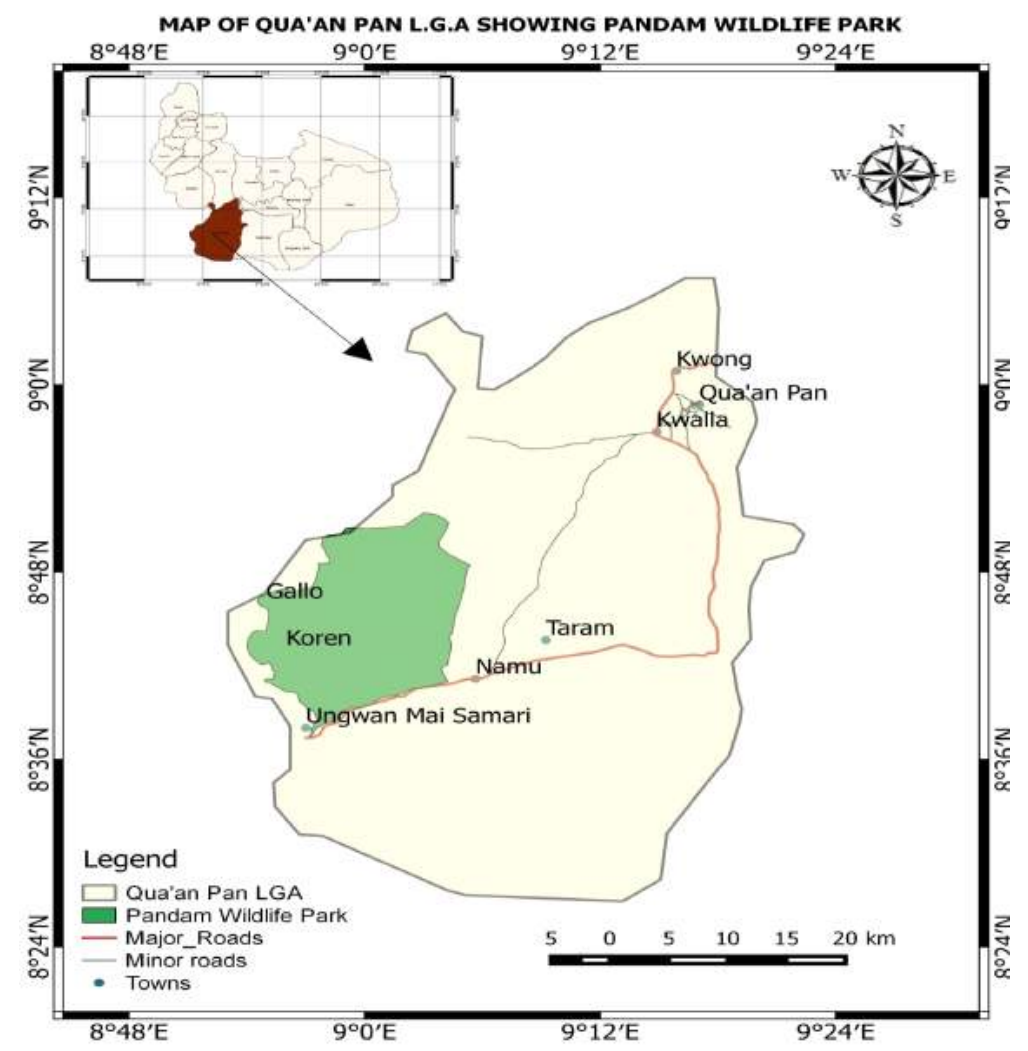

Fig. 2: Qua'an Pan L.G.A Showing Pandam Game Reserve Source: Plateau State Ministry of Land and Survey, 2010.

\section{Data Collection}

The researchers adopted a survey pattern of research for the study, which included field study, personal interviews, and the use of questionnaire to ensure that required data were collected. For reliability and proficiency in this study, a structured questionnaire of about 400 was administered to the host communities, students, professionals in ecotourism and business men. This provided insight to the management problems in Pandam Game Reserve.

\section{Data Analysis}

Results obtained from the questionnaires distributed were analyzed using descriptive statistics in form of percentages and frequency of counts.

\section{Sampling Frame and Techniques}

Simple random sampling technique was used to sample population within the study area. The simple random technique gives each member of the population an equal chance of being selected.

The sample size for this research was statistically determined using "Taro Yamane" (1967) Formula:

$$
\mathrm{n}=\quad \mathrm{N}
$$

Where:

$\mathrm{n}$ is the sample size: 
$\mathrm{N}$ is the finite population,

$\mathrm{E}$ is the level of significance (limit of tolerable error), that is $0.05(5 \%)$ and

$\mathrm{L}$ is unity (a constant).

$\mathrm{n}=295914 / 1+295914 \times(0.05)^{2}$

$\mathrm{n}=295914 / 1+295914 \times(0.0025)$

Therefore, $\mathrm{n}=295914 / 739=400$ (target population)

Using the sample frame formula with 2017 projected population of 295,914, approximately 400 respondents were sampled at 0.05 level of significance.

A stratified sample technique was used; a random sample from each stratum is taken in a number supposedly proportional to the stratum's size when compared to the population. These subsets of data were then pooled to form a random sample. This technique captures key population characteristics and was most suitable for this study because it provided information about the population attributes. Stratified random sampling is a method of sampling that involves the division of a population into smaller groups known as strata.

\section{Results and Discussion}

The data on table 1 presents the age composition of the respondents.

Table 1: Age of Respondents

\begin{tabular}{|l|l|l|}
\hline Age & Respondents & Percentage (\%) \\
\hline $18-25$ & 50 & 12.6 \\
\hline $25-35$ & 110 & 27.8 \\
\hline $35-45$ & 109 & 27.5 \\
\hline 45 and above & 127 & 32.1 \\
\hline Total & $\mathbf{3 9 6}$ & $\mathbf{1 0 0}$ \\
\hline
\end{tabular}

Table 1 shows that the respondents within the age bracket of 18-25 have the lowest number in the survey, representing 12.6 percent. This is followed by 35-45 age bracket, representing 27.5 percent. $25-35$ age bracket has 27.8 percent representing 110 respondents, while age from 45 and above has the highest number of respondents with 32.1 percent representing 127 people.

Table 2: Gender of Respondents

\begin{tabular}{|l|l|l|}
\hline Gender & Frequency & Percentage (\%) \\
\hline Male & 150 & 37.8 \\
\hline Female & 246 & 62.2 \\
\hline Total & $\mathbf{3 9 6}$ & $\mathbf{1 0 0}$ \\
\hline
\end{tabular}

From Table 2, it shows that 150 respondents are males representing 37.8 percent and 246 respondents are females representing 62.2 percent. This shows that the number of females in the survey is higher than the males.

Table 3: Marital Status of Respondents

\begin{tabular}{|l|l|l|}
\hline Marital Status & Frequency & Percentage (\%) \\
\hline Single & 230 & 58.1 \\
\hline Married & 90 & 22.7 \\
\hline Separated & 46 & 11.6 \\
\hline Divorce & 30 & 7.6 \\
\hline
\end{tabular}


Table 3 shows that 230 of the respondents representing 58.1 are singles, 90 respondents representing 22.7 percent are married, 46 respondents representing 11.6 percent are separated, while 30 respondents representing 7.6 percent are divorce.

Table 4: Educational Qualification of Respondents

\begin{tabular}{|l|l|l|}
\hline Educational Qualification & Respondents & Percentage (\%) \\
\hline Primary School & 40 & 10.1 \\
\hline Secondary School & 196 & 49.5 \\
\hline Graduate & 104 & 26.3 \\
\hline Postgraduate & 56 & 14.1 \\
\hline Total & $\mathbf{3 9 6}$ & $\mathbf{1 0 0}$ \\
\hline
\end{tabular}

Table 4 shows that 40 respondents representing 10.1 percent have only primary school qualification, 196 members representing 49.5 percent have secondary school qualification, 104 respondents representing 26.3 percent have are graduates with HND and first degree qualification, while 56 respondents representing 14.1 percent have postgraduate qualification.

Table 5: Occupation of Respondents

\begin{tabular}{|l|l|l|}
\hline Occupation & Respondents & Percentage (\%) \\
\hline Students & 97 & 24.4 \\
\hline Farmers & 100 & 25.4 \\
\hline Tourism consultants & 63 & 15.9 \\
\hline Business men & 136 & 34.3 \\
\hline Total & $\mathbf{3 9 6}$ & $\mathbf{1 0 0}$ \\
\hline
\end{tabular}

Table 5 shows that 97 respondents representing 24.4 percent are students, 100 members representing 25.4 percent are farmers, 63 respondents representing 15.9 percent are tourism consultants, while 136 respondents representing 34.3 percent are business men.

Table 6: Management Problems in Pandam Game Reserve

\begin{tabular}{|l|l|l|}
\hline Option & Frequency & Percentage (\%) \\
\hline Inadequate infrastructures & 0 & 0 \\
\hline Shortage of Staff Strength & 60 & 15.2 \\
\hline In-adequate Funds & 29 & 7.3 \\
\hline All of the above & 307 & 77.5 \\
\hline Total & $\mathbf{3 9 6}$ & $\mathbf{1 0 0}$ \\
\hline
\end{tabular}

Table 6 shows the level of management problems which are observed at Pandam Game Reserve. It shows that 0 percent respondents are of the opinion that inadequate infrastructures are the major problem in Pandam Game Reserve, 15.2 percent says shortage of staff strength, 7.3 percent says inadequate funds and 77.5 percent says all of the above, and this has the highest number of respondents; this might be because all the above options are indices that need to be put in place for the smooth and successful running of the reserve, hence calling for government intervention. 
Table 7: Major Problems faced by the Management of Pandam Game Reserve

\begin{tabular}{|l|l|l|}
\hline Option & Frequency & Percentage (\%) \\
\hline Poaching & 40 & 10.0 \\
\hline Land encroachment & 60 & 15.2 \\
\hline Deforestation & 6 & 1.5 \\
\hline All of the above & 290 & 73.3 \\
\hline Total & $\mathbf{3 9 6}$ & $\mathbf{1 0 0}$ \\
\hline
\end{tabular}

Table 7 reveals the major problems faced by the management of Pandam Game Reserve. It shows that 40 respondents $(10.0 \%)$ opine that Poaching is the major problem faced by the management, 60 respondents $(15.2 \%)$ are of the view that land encroachment is the major problem, 6 respondents $(1.5 \%)$ say deforestation, whereas 290 respondents $(73.3 \%)$ indicate that both poaching, land encroachment and deforestation are the major problems faced by the management of Pandam Game Reserve; this has the highest number of respondents. Therefore, there is a need for the Government to monitor and contain the activities of people around and within the Pandam Game Reserve. It is very pertinent that State Government gives proper attention to the implementation of tourism policies in Pandam Game Reserve. It is also very important that the community is involved in the management procedures.

Table 8: Are Stakeholders involved in the Management of Pandam Game Reserve on tourism matters?

\begin{tabular}{|l|l|l|}
\hline Option & Frequency & Percentage (\%) \\
\hline Strongly agreed & 200 & 50.5 \\
\hline Strongly disagreed & 90 & 22.7 \\
\hline Agreed & 6 & 1.5 \\
\hline Disagreed & 100 & 25.3 \\
\hline Total & $\mathbf{3 9 6}$ & $\mathbf{1 0 0}$ \\
\hline
\end{tabular}

Table 8 indicates the level of stakeholders' involvement in the management of Pandam Game Reserve. It shows that 200 respondents (50.5\%) strongly agreed that stakeholders are involved in the management of Pandam Game Reserve, 90 respondents $(22.7 \%)$ strongly disagreed, 6 respondents $(1.5 \%)$ agreed, while $100(25.3 \%)$ disagreed. However, the 50.5 percent of the respondents which indicates the involvement of stakeholders in the management of Pandam Game Reserve is quite encouraging, but the stakeholders need to make more efforts to curb the problems at Pandam Game Reserve, hence make it more attractive to the tourists.

Table 9: How can Pandam Game Reserve be developed to international standard?

\begin{tabular}{|l|l|l|}
\hline Option & Frequency & Percentage (\%) \\
\hline Provision of adequate infrastructures & 106 & 26.7 \\
\hline Inviting foreign investors & 200 & 50.6 \\
\hline Provision of adequate funds & 90 & 22.7 \\
\hline Total & $\mathbf{3 9 6}$ & $\mathbf{1 0 0}$ \\
\hline
\end{tabular}

Table 9 shows the various ways of developing the Pandam Game Reserve to the international standard. Out of the 396 respondents, $106(26.7 \%)$ respondents are of the view that provision of adequate infrastructures could help develop Pandam Game Reserve to international standard, $200(50.6 \%)$ respondents indicate that inviting foreign investors 
would help, while $90(22.7 \%)$ respondents indicate that provision of adequate funds would help. Amongst the options, inviting foreign investors with 50.6 percent has the highest respondents. As such, inviting foreign investors could solve the problem of sustainable tourism development in Pandam Game Reserve, as it would foster more development and help Pandam Game Reserve grow to the international standard.

Table 10: Solutions to Management Problems in Pandam Game Reserve

\begin{tabular}{|l|l|l|}
\hline Option & Frequency & Percentage (\%) \\
\hline Equip rangers with modern facilities & 30 & 7.6 \\
\hline Increase staff strength & 20 & 5.1 \\
\hline Pay staff salaries as at when due & 40 & 10.0 \\
\hline All of the above & 306 & 77.3 \\
\hline Total & $\mathbf{3 9 6}$ & $\mathbf{1 0 0}$ \\
\hline
\end{tabular}

Table 10 shows the various ways of solving the management problems in Pandam Game Reserve. Out of the 396 respondents, 30 respondents which represent 7.6 percent of the entire sample population are of the view that equipping rangers with modern facilities would solve the management problems in Pandam Game Reserve. However, 20 (5.1\%) respondents assert that the management problems could be solved by increasing the staff strength. 40 respondents which account for 10.0 percent opine that payment of staff salaries as at when due would solve the management problems. Furthermore, 306 respondents which account for 77.3 percent of the sample population indicate that equipping rangers with modern facilities, increasing the staff strength, and payment of staff salaries would altogether solve the management problems in Pandam Game Reserve.

Table 11: Measures that could best be used to curb the problems of ecosystem destruction by the host communities

\begin{tabular}{|l|l|l|}
\hline Option & Frequency & Percentage (\%) \\
\hline Outreach programs to schools and worship centers & 30 & 7.6 \\
\hline Stakeholders' involvement on tourism matters & 45 & 11.4 \\
\hline $\begin{array}{l}\text { Poachers and farmers be employed in Pandam } \\
\text { Game Reserve }\end{array}$ & 25 & 6.3 \\
\hline All of the above & 296 & 74.7 \\
\hline Total & $\mathbf{3 9 6}$ & $\mathbf{1 0 0}$ \\
\hline
\end{tabular}

Table 11 shows the various measures that could best be used to curb the problems of ecosystem destruction by the host communities. $30(7.6 \%)$ respondents out of the 396 respondents state that outreach programs to schools and worship centers is the best option for curbing the problems of ecosystem destruction by the host communities. 45 respondents which account for 11.4 percent are of the opinion that stakeholders' involvement on tourism matters stand the best option. Furthermore, 25 respondents which represent 6.3 percent of the sample population assert that employing poachers and farmers in Pandam Game Reserve is the best option. All in all, 296 respondents which represent 74.7 percent of the respondents state that combining the three measures (which include outreach programs to schools and worship centers, stakeholders' involvement on tourism matters, and employing poachers and farmers in Pandam Game Reserve) would be the best measure to curb the problems of ecosystem destruction by the host communities of Pandam Game Reserve. 


\section{Conclusion and Recommendation}

The result apparently reveals that inadequate infrastructures, shortage of staff strength and inadequate funds altogether form the management problems bedeviling the Pandam Game Reserve. It is also shown that both poaching, land encroachment and deforestation are the major problems faced by the management of Pandam Game Reserve. Additionally, result indicates that greater percentage of the respondents agree that stakeholders are involved in the management of Pandam Game Reserve. More so, amongst all the options for developing the Pandam Game Reserve to international standard, inviting foreign investors with the highest percentage stand the best option, and as such would solve the problem of sustainable tourism development in Pandam Game Reserve.

The study also opines that equipping rangers with modern facilities, increasing the staff strength, and payment of staff salaries would altogether solve the management problems in Pandam Game Reserve. Furthermore, the study asserts that combining the three measures (which include outreach programs to schools and worship centers, stakeholders' involvement on tourism matters, and employing poachers and farmers in Pandam Game Reserve) would be best to curb the problems of ecosystem destruction by the host communities of Pandam Game Reserve.

The study therefore recommends government intervention to reposition the Pandam Game Reserve to be of international standard. This would include, but not limited to provision of infrastructures, increasing the staff strength, and provision of funds. The study also recommends that Government monitors and contains the activities of the people around and within the Pandam Game Reserve in order to avoid poaching, land encroachment and deforestation. Furthermore, it recommends that State Government gives proper attention to the implementation of tourism policies in Pandam Game Reserve. Also, it recommends the community involvement in the management procedures of Pandam Game Reserve. The study also recommends that the stakeholders should make more efforts to curb the problems at Pandam Game Reserve, hence make it more attractive to the tourists. Additionally, the study recommends that foreign investors should be invited in order to help develop the Pandam Game Reserve to be of international standard, and thus solve the problem of sustainable tourism development in Pandam Game Reserve. To curb ecosystem destruction at Pandam Game Reserve, the study recommends outreach and sensitization programs, stakeholders' involvement and employing some community members, especially the poachers and farmers.

\section{Research Limitation and Direction for Future Studies}

The study was not funded by any organization or institution, hence the reason for limiting the study to its scope. For future studies, it is of high necessity that the present study is carried out in other game reserves within the country and beyond. That, among other things, would help to unveil the management problems which are peculiar to each game reserve, and would also discuss other management problems which are not discussed in this study.

\section{References}

Adeleke, B. O. and Ogunsusi, K. (2019). Evaluation of factors enhancing effectiveness of destination management of nature based tourism, Lagos, Nigeria. International Tourism and Hospitality Journal, 2(2), 1-16. 
Akosim, C. (1997). Evaluation of biodiversity conservation and management in Pandam Wildlife Park, Plateau State, Nigeria. PhD thesis, Department of Wildlife and Fisheries Management, University of Ibadan, $232 \mathrm{pp}$.

Alamai, M. M., Kirfi, U. H., and Ladi, A. F. (2018). Tourism and the economy of Nigeria: A synthesis of its contributions to GDP from 2005-2016. Advances in Social Sciences Research Journal, 5(11), 256-263.

Da'an, S. A., Jidangkat, M., Chaskda, A. A., and Mwansat, G. S. (2020). Livelihoods and biodiversity conservation: A survey of socioeconomic activities around Pandam Game Reserve, Plateau State - Nigeria. Journal of Applied Science and Environmental Management, 24(6), 979-983.

Eagles, P. F. J. (2002). Trends in Park Tourism: Economics, finance and management. Journal of Sustainable Tourism, 10(2) 132-153.

Eneji, Odey, and Bullus (2016). Diversification of Nigeria's economy: Impact of tourism on sustainable development in Nigeria. International Journal of Research in Humanities and Social Studies, 3(5), 36-44.

Ezealor, U. (2002). Critical sites for biodiversity conservation in Nigeria. Nigerian Conservation Foundation, Logos, $110 \mathrm{pp}$.

Ijeomah, H. M. (2007). Impacts of tourism on perceived poverty alleviation in Plateau State. PhD thesis, Department of Wildlife and Fisheries Management, University of Ibadan, $301 \mathrm{pp}$.

Jansen, M. (2013). Aid for trade and value chains in trourism. World Trade Organisation.

Jemirade, D. (2021). Tourism: The missed opportunities for economic development in Nigeria. Journal of African Studies and Development, 3(1), 15-22.

Khan, A., Bibi, S., Lorenzo, A., Lyu, J., and Babar, Z. U. (2020). Tourism and development in developing economies: A policy implication perspective. Sustainability, 12, 1618.

Mason, P. (2003). Tourism impacts, planning and management. Butterworth-Heinemann: Oxford.

Ndanusa, M. M., Harada, Y, and Islam, M. A. (2014). Challenges to growth in tourism industry of a developing country: The case of Nigeria. Asian Social Science 10(19), 282-290.

Nimmak, S. P., \& Onwuadiochi, I. C. (2020). Assessment of the socio-cultural and economic challenges of ecotourism industry in Pandam Game Reserve, Plateau State, Nigeria. IOSR Journal of Environmental Science, Toxicology and Food Technology. (IOSR-JESTFT), 14(6), 22 - 32. DOI: 10.9790/2402-1406012232

Nimmak, S. P., Phil-Eze, P. O., Ezenwaji, E. E., \& Onwuadiochi, I. C. (2020). Environmental challenges of ecotourism in Pandam Game Reserve, Plateau State, Nigeria. IOSR Journal of Environmental Science, Toxicology and Food Technology (IOSR-JESTFT), 14(7), 07-16.

Osinubi, T., Osinubi, O. B., Tabash, M. I., Ajayi, A. O., and Tran, K. D. (2021). The Impact of Corruption on Tourism Sector in Nigeria: Empirical Insights by Using an Autoregressive Distributed Lag Bounds (ARDL) Testing Approach. International Journal of Hospitality and Tourism Administration.

Sreekumar, T. T. and Parayil, G. (2002). Contentions and contradictions of tourism as development option: The Case of Kerala, India. Third World Quarterly, 23(3), 529548. 